\title{
Role of toxoplasmosis in the aetiology of some cardiac diseases: an immunobiological investigation
}

\author{
D ŠIBALIĆ, O DJURKOVIĆ-DJAKOVIĆ \\ From the Institute for Medical Research, Belgrade, Yugoslavia
}

SUMmARY The Sabin-Feldman dye test was used to show the presence of toxoplasma antibodies in 183 patients with cardiac disease, as well as in two control groups (A and B), comprising 183 and 2186 healthy subjects, respectively. Toxoplasma specific antibodies were found in $157(86 \%) \mathrm{pa}-$ tients with cardiac disease, $39(21 \%)$ of whom had high titres. The prevalence of toxoplasma antibodies was considerably lower than that of control groups: 94 (51\%) in group A and 1276 $(58 \%)$ in group B. High titres were present in $8(4 \%)$ and $83(4 \%)$, respectively. Immunofluorescence antibody testing showed $\operatorname{IgM}$ antibodies in five patients, three of whom had the organism itself recovered from the blood or lymph nodes.

Chronic or latent toxoplasma infection as a cause of cardiac disease is not as uncommon as is generally thought.

The organism Toxoplasma gondii attacks all tissues of the host, reproducing itself intensively during the acute phase. When immunity has developed in the host $T$ gondii withdraws into the brain, muscles, and other organs where it becomes encysted. Acute toxoplasmosis is usually asymptomatic; when it becomes clinically apparent the disease manifestations are protean. $T$ gondii infection exists in a chronic asymptomatic form in about $50 \%$ of the population of Yugoslavia. ${ }^{12} \mathrm{Siim}^{3}$ was the first to describe the clinical features of acute acquired toxoplasmosis. Exanthematous and encephalitic forms of acquired toxoplasmosis cause cardiac diseases in $50 \%$ of patients. ${ }^{4}$ Cysts in cardiac muscle, probably toxoplasmatic in origin, were first described by Kean and Grocott in $1945 .^{5}$ Subsequently, these parasites were found in myocardial fibres in large aggregates and cysts without a surrounding inflammatory reaction. Experimental studies on rabbits and hamsters ${ }^{67}$ showed that myocarditis probably occurs after the rupture of affected cells, which liberate the parasites and cause an inflammatory reaction in the surrounding tissue. ${ }^{8}$ Later investigations indicated that $T$ gondii was found far more often in the heart than in other organs. The most recent investigations show that cardiac transplantation from a seropositive donor to a seronegative recipient can result in severe infection which can be fatal. ${ }^{9}$

Accepted for publication 14 October 1985
As the relation between cardiac disease and toxoplasmosis has hardly been investigated, we carried out a systematic study of this problem, concentrating on the role of acute acquired toxoplasmosis in myocardial disease.

\section{Material and methods}

Sera were obtained from 130 men and 53 women with some form of heart infection or degenerative cardiac disease, aged from 14-54 years. The patients were classified into five age groups: I, 10-19; II, 20-29; III, 30-39; IV, 40-49; and V, > 50. Two control groups were also included in this study: control group A consisted of the same number of healthy subjects matched for age and sex, and control group B consisted of 2186 subjects who had served as healthy controls in a previous investigation, but who were not matched for age and sex: subjects over 40 years of age were classified into one age group. ${ }^{10}$

The persistence of toxoplasma antibodies was shown by the Sabin-Feldman dye test ${ }^{11}$ modified by Desmonts into the lysis test. ${ }^{12}$ Sera were diluted $1 / 10$, $1 / 100,1 / 1000$, or higher if necessary. The titres reported were the final dilutions of the sera in the reacting mixtures.

Specific IgM antibodies were shown by the IgM indirect fluorescence antibody test IgM-IFAT, ${ }^{13}$ using "bio-Mérieux" reagents. Sera were diluted $1 / 50$, $1 / 100,1 / 200$, or higher if necessary. Attempts were 
Table 1 Distribution of toxoplasma antibodies in patients with cardiac disease and in control groups

\begin{tabular}{|c|c|c|c|c|c|c|c|c|c|c|c|c|}
\hline \multirow{2}{*}{$\begin{array}{l}\text { Age } \\
\text { (years) }\end{array}$} & \multicolumn{3}{|c|}{ Patients with cardiac disease titre } & \multirow{2}{*}{$\begin{array}{l}\text { Total No } \\
\text { examined }\end{array}$} & \multicolumn{3}{|c|}{ Control Group A titre } & \multirow{2}{*}{$\begin{array}{l}\text { Total No } \\
\text { examined }\end{array}$} & \multicolumn{3}{|c|}{ Control group B titre } & \multirow{2}{*}{$\begin{array}{l}\text { Total No } \\
\text { examined }\end{array}$} \\
\hline & 10 & 100 & $>100$ & & 10 & 100 & $>100$ & & 10 & 100 & $>100$ & \\
\hline $\begin{array}{l}10-19 \\
20-29 \\
30-39 \\
40-49 \\
\text { Over } 50 \\
\text { Total }\end{array}$ & $\begin{array}{r}10 \\
6 \\
10 \\
8 \\
34\end{array}$ & $\begin{array}{l}5^{*} \dagger \\
10^{*} \\
21 \\
24 \\
24 \\
84\end{array}$ & $\begin{array}{l}6 \dagger \\
8^{*} \dagger \\
7 \\
18 \\
39\end{array}$ & $\begin{array}{r}7 \\
31 \\
45 \\
46 \\
54 \\
183\end{array}$ & $\begin{array}{r}2 \\
6 \\
12 \\
8 \\
5 \\
33\end{array}$ & $\begin{array}{r}3 \\
11 \\
20 \\
13 \\
6 \\
53\end{array}$ & $\begin{array}{l}3 \\
3 \\
1 \\
1 \\
8\end{array}$ & $\begin{array}{r}14 \\
68 \\
52 \\
31 \\
18 \\
183\end{array}$ & $\begin{array}{r}88 \\
134 \\
90 \\
112 \\
\\
424\end{array}$ & $\begin{array}{l}106 \\
190 \\
253 \\
220 \\
\\
769\end{array}$ & $\begin{array}{l}28 \\
18 \\
19 \\
18 \\
\\
83\end{array}$ & $\begin{array}{r}356 \\
574 \\
646 \\
610 \\
\\
2186\end{array}$ \\
\hline
\end{tabular}

*parasite isolated.

+IgM IFAT positive.

made to isolate $T$ gondii by inoculating suspected material (blood samples and peripheral lymph nodes) into Swiss albino mice.

Statistical analysis was carried out using the $\chi^{2}$ test, while small groups were analysed by the Fischer test for absolute probability and Student's $t$ test for proportions.

\section{Results}

Table 1 shows the prevalence of infection with $T$ gondii and the distribution of the titres obtained in various age groups among the patients with cardiac disease and in the controls. Of the 183 patients with cardiac disease, toxoplasma antibodies were found in $157(86 \%)$. A titre of $1 / 1000$ or higher was found in 39 patients $(21 \%)$. Two or more serum samples were available from 40 patients; the titre increased in 17 patients and decreased in five.

In contrast, toxoplasma antibodies were found in only $94(51 \%)$ patients in control group $A$ and in 1276 $(58 \%)$ in control group B, while high titres $>1 / 100$ were found in $8(4 \%)$ and $83(4 \%)$, respectively.

It was apparent that toxoplasma antibodies in high titres were far more common among patients with cardiac disease than in the control groups. Statistical analysis showed that there were significant differences between the patients and the control groups both in the prevalence of toxoplasma antibodies $\chi^{2}=50 \cdot 324$ and $\chi^{2}=53.118, p<0.01$ of high titres, $\chi^{2}=10.303$ and $\chi^{2}=131.42, \mathrm{p}<0.01$.

The distribution of positive findings by SabinFeldman dye test varied among the age groups. Table 2 shows the statistical analysis. In the youngest age group (10-19 years) no significant difference in the prevalence of toxoplasma antibodies was found between the patients and either control group. In all the other age groups, however, a significant difference was shown, with the exception of patients in the group III age group (30-39 years) compared with the subjects of control group $A$ of the same age.

There were far more men than women in the group with cardiac disease (Table 3) than in control group A ( $71 \%$ and $45 \%$, respectively). This discrepancy can be explained by the fact that we were able to cooperate mostly with cardiologists practising in male departments. On the other hand, the number of women in control group A was slightly greater because the group was derived from hospital administrative employees, many of whom are women.

In spite of the predominance of men in our study statistical comparison of the results obtained from men and women showed no significant difference $\left(\chi^{2}\right.$ $=1.363 ; \mathrm{p}>0.05$ ) which implies that heart disorders associated with toxoplasmosis can be expected in both sexes at the same rate.

The patients with cardiac disease were divided into two large groups according to whether the course of the disease was acute or chronic. Some form of heart infection (acute myocarditis, acute myopericarditis, acute pancarditis) was present in $74(47 \%) ; 83(53 \%)$ had degenerative disease (cardiomyopathy) (Table 4), while the remaining 26 patients had cardiac disorders of undefined type. The distribution among the age groups was not even-acute disease was far more common than chronic disease $(57 \%: 25 \%)$ in the younger patients; among the patients in group II about the same number had both acute and chronic

Table 2 Statistical comparison of positive findings by Sabin-Feldman dye test between patients with cardiac disease and control groups

\begin{tabular}{llll}
\hline Age (in years) & Control group A & $p$ & Control group B \\
\hline $10-19$ & $p=0119$ & $>0.05$ & $T_{t}=0487$ \\
$20-29$ & $\chi^{2}=2541$ & $\leqslant 0.01$ & $\chi_{2}^{2}=7283$ \\
$30-39$ & $\chi^{2}=132$ & $>0.05$ & $\chi^{2}=83$ \\
$40-49$ & $\chi^{2}=4095$ & $\leqslant 0.05$ & $\chi^{2}=41272$ \\
Over 50 & $\chi^{2}=6086$ & $\leqslant 0.05$ & 50.05 \\
\hline
\end{tabular}


Table 3 Distribution of toxoplasma antibodies in patients with cardiac disease and in control group according to age and sex

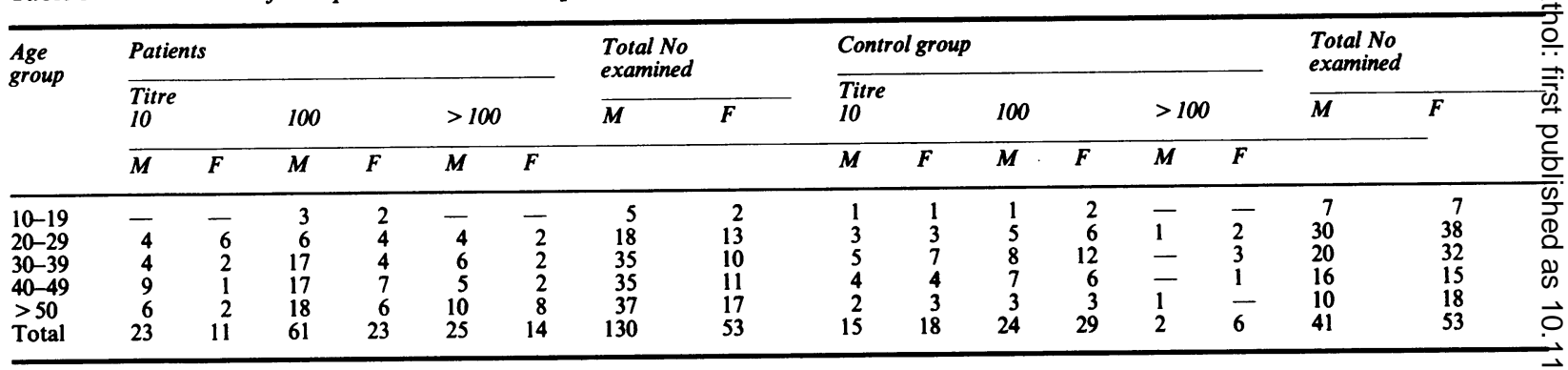

Table 4 Distribution of toxoplasma antibodies in acute and chronic cases of cardiac disease according to age and sex

\begin{tabular}{|c|c|c|c|c|c|c|c|c|c|c|c|c|c|c|c|c|}
\hline \multirow{4}{*}{$\begin{array}{l}\text { Age } \\
\text { group }\end{array}$} & \multicolumn{6}{|c|}{ Acute disease } & \multirow{2}{*}{\multicolumn{2}{|c|}{$\begin{array}{l}\text { Total No } \\
\text { examined }\end{array}$}} & \multicolumn{6}{|c|}{ Chronic disease } & \multirow{2}{*}{\multicolumn{2}{|c|}{$\begin{array}{l}\text { Total No } \\
\text { examined }\end{array}$}} \\
\hline & \multirow{2}{*}{\multicolumn{2}{|c|}{$\begin{array}{l}\text { Titre } \\
10\end{array}$}} & \multirow{2}{*}{\multicolumn{2}{|c|}{100}} & \multirow{2}{*}{\multicolumn{2}{|c|}{$>100$}} & & & \multirow{2}{*}{\multicolumn{2}{|c|}{$\begin{array}{l}\text { Titre } \\
10\end{array}$}} & \multirow{2}{*}{\multicolumn{2}{|c|}{100}} & \multirow{2}{*}{\multicolumn{2}{|c|}{$>100$}} & & \\
\hline & & & & & & & $M$ & $F$ & & & & & & & \multirow[t]{2}{*}{$\bar{M}$} & \multirow[t]{2}{*}{$F$} \\
\hline & $M$ & $F$ & $M$ & $F$ & $M$ & $F$ & & & $M$ & $F$ & $M$ & $F$ & $M$ & $F$ & & \\
\hline $\begin{array}{l}10-19 \\
20-29 \\
30-39 \\
40-49 \\
>50 \\
\text { Total }\end{array}$ & $\begin{array}{r}-2 \\
2 \\
5 \\
2 \\
11\end{array}$ & $\begin{array}{l}- \\
5 \\
1 \\
1 \\
1 \\
8\end{array}$ & $\begin{array}{r}1 \\
5 \\
4 \\
5 \\
3 \\
18\end{array}$ & $\begin{array}{l}\frac{1}{2} \\
2 \\
2 \\
7\end{array}$ & $\begin{array}{l}- \\
2 \\
5 \\
1 \\
1 \\
9\end{array}$ & $\frac{\overline{2}}{-}$ & $\begin{array}{r}2 \\
11 \\
16 \\
13 \\
7 \\
49\end{array}$ & $\begin{array}{r}1 \\
8 \\
3 \\
4 \\
9 \\
25\end{array}$ & $\begin{array}{l}-1 \\
2 \\
3 \\
2 \\
8\end{array}$ & $\begin{array}{l}\frac{1}{1} \\
\frac{-}{2}\end{array}$ & $\begin{array}{r}1 \\
2 \\
11 \\
13 \\
11 \\
38\end{array}$ & $\begin{array}{l}- \\
\overline{1} \\
2 \\
3 \\
6\end{array}$ & $\begin{array}{r}-1 \\
4 \\
8 \\
13\end{array}$ & $\begin{array}{l}-1 \\
1 \\
1 \\
3 \\
6\end{array}$ & $\begin{array}{r}2 \\
5 \\
16 \\
22 \\
23 \\
68\end{array}$ & $\begin{array}{r}-4 \\
2 \\
2 \\
6 \\
15\end{array}$ \\
\hline
\end{tabular}

disease; and among the oldest (groups IV and V) more patients had some form of chronic heart disease (33\%: $54 \%$ and $33 \%: 50 \%$, respectively). Among the sixteen patients with acute cardiac diseases in the eldest age group nine were women, six of whom had high titres of toxoplasma antibodies.

The IgM-IFAT was conducted on the first serum sample obtained from each of the patients. Specific IgM antibodies were detected in five of the 183 sera examined, though the titres were low (Table 1). The finding of low titres of specific IgM antibodies indicated that the infection with $T$ gondii had been contracted months or possibly a year earlier.

Isolation of the organism was attempted by inoculating suspected blood samples or peripheral lymph nodes into mice in 14 cases. Isolation was successful in three cases (Table 1).

\section{Discussion}

Although there are a great many publications on cardiac toxoplasmosis, these are mostly case reports in which, after thorough clinical and laboratory examinations, toxoplasmosis was diagnosed serologically and confirmed by successful isolation of $T$ gondii in some cases. ${ }^{14-21}$

Ludlam and Somers ${ }^{22}$ examined the incidence of toxoplasma antibodies in patients with cardiac disease and in healthy blood donors in Uganda: their results did not allow them to postulate that toxoplasmosis is a potential cause of heart trouble in any age group. In contrast, our study showed a high prevalence of toxoplasma antibodies in patients with cardiac disease $(86 \%)$ compared with those of the control groups $(51 \%)$ and $(58 \%)$, respectively. These findings indicate that $T$ gondii might be the aetiological factor in many cases of heart disease. Our study also included the detection of specific IgM antibodies, the presence and especially the rise of which would indicate recent infection with $T$ gondii. The results obtained both by the Sabin-Feldman dye test and the IgM-IFAT suggested that heart disorders are seldom associated with acquired toxoplasmosis in the first few months after infection: if this occurs it is mostly in younger age groups. Thus it is more likely that heart disease develop a few years later, after the encystation of the organism and the consecutive reactivation of the illness (serologically shown by high stable titres with the Sabin-Feldman dye test or by slight titre variation in the absence of specific IgM antibodies).

Specific IgM antibodies were found mainly in younger patients. In patients in whom they had not been shown absence did not necessarily mean that the disease had a chronic course; Remington et al, ${ }^{13}$ Desmonts et al, ${ }^{23}$ and Couvreur ${ }^{24}$ established that in $10 \%$ of cases of confirmed acute infection the IgMIFAT yielded negative results. 
The problem of chronic toxoplasmosis is especially relevant nowadays as there are numerous reports of cases of reactivation of latent (chronic) toxoplasmosis in malignant disease, treatment with immunosuppressive drugs, or in elderly people in whom physiological immunosuppression occurs.

Cardiac disease from toxoplasmosis is considered to be extremely rare. Our investigation shows, however, that certain cardiac diseases might be caused by chronic or latent toxoplasma infection. Therefore, in all cases of cardiac disease of unclear aetiology provided symptomatology of acquired toxoplasmosis had occurred (along with a negative Paul-Bunnel test, which excludes infective mononucleosis that may have similar symptomatology), toxoplasmosis should be borne in mind.

This study was supported by a grant from the Medical Research Foundation of Serbia.

\section{References}

${ }^{1}$ Sibalić D, Radović M. Contribution à la connaissance de la fréquence de l'infection de Toxoplasma gondii chez l'homme dans la Serbie. CCLXXV SRPSKA AKADEMIJA NAUKA I UMETNOSTI Odeljenje medicinskih nauka 1969;9:2285-91.

${ }^{2}$ Sibalić D, Radović M, Martinović M. Incidence des infections par Toxoplasma gondii chez des personnes de professions differentes. Comptes-rendus ler multicolloque européen de parasitologie Rennes 1-4 Sept 1971:261-4.

${ }^{3}$ Siim J. Toxoplasmosis: toxoplasmosis aquisita lymphonodosa: clinical and pathological aspects. Ann $N Y$ Acad Sci 1956;64:185-206.

4 Francois J. La toxoplasmose et ses manifestations oculaires. Paris: Masson, 1963.

${ }^{5}$ Kean BH, Grocott RG. Sarcosporidiosis and toxoplasmosis in man and guinea pig. Am J Pathol 1945;21:467-83.

${ }^{6}$ Mohr H, Honig H. Myocardioschädigung bei Protozoenerkrankungen insbesondere bei Toxoplasmose. Verh Dtsch Ges Inn Med 1953;14:429-31.

${ }^{7}$ Henry L, Beverley JKA, Archer JF, Jonson SG. Experimental toxoplasmic myocarditis in rabbits. $J$ Pathol 1973;109:141-9.

${ }^{8}$ Remington JS, Klein JO. Infectious diseases of the fetus and the newborn infant. Philadelphia: WB Saunders Co, 1976.

${ }^{9}$ McGregor CGA, Fleck DG, Nagington J, Stovin PGI, CoryPearce RR, English TAH. Disseminated toxoplasmosis in cardiac transplantation. J Clin Pathol 1984;37:74-7.

${ }^{10}$ Sibalić D. Incidence of toxoplasma gondii infection in man and in various animals in some areas of Serbia. Acta Parasitologica Iugoslavica 1977;1:13-8.

${ }^{11}$ Sabin A, Feldman HA. dyes as microchemical indicators of a new immunity phenomenon affecting a protozoan parasite (Toxoplasma). Science 1984: 660-3.

${ }^{12}$ Desmonts G. Sur la technique de l'épreuve de lyse des toxoplasmes. Sem Hôp Paris 1955;31:193-8.

${ }^{13}$ Remington JS, Miller MJ, Brownlee I. IgM antibodies in acute toxoplasmosis. I Diagnostic significance in congenital cases and a method for their rapid demonstration. Pediatrics 1968;41:1082-91.

${ }^{14}$ Callahan WP Jr, Russel WO, Smith MG. Human toxoplasmosis; a clinicopathological study, with presentation of 5 cases and review of the literature. Medicine 1946;25:343-97.

${ }^{15}$ Hakkila J, Frick MM, Halonen PI. Pericarditis and myocarditis caused by Toxoplasma: report of a case and review of the literature. Am Heart J 1958;55:758-65.

${ }^{16}$ Jones TC, Kean BH, Kimball AC. Pericarditis associated with toxoplasmosis. Ann Intern Med 1965;62:786.

${ }^{17}$ Shafer N. Toxoplasmosis. In: Turrell R, ed. Recent advances in medicine and surgery. New York: 1975: 1049-61.

${ }^{18}$ Mirada A, Rubies-Prat J, Cerda E, Foz M. Pericarditis associated with acquired toxoplasmosis in a child. Cardiology 1976;61:303-6.

${ }^{19}$ Leak D, Meghji M. Toxoplasmic infection in cardiac disease. Am J Cardiol 1979;43:841-9.

${ }^{20}$ Cunningham T. Pancarditis in acute toxoplasmosis. Am J Clin Pathol 1982;78:403-5.

21 Durge NG, Baqui MN, Ward R. Myocardial toxoplasmosis. Lancet 1967; ii: 155.

${ }^{22}$ Ludlam GB, Somers K. Incidence of toxoplasma antibodies in Ugandans with special reference to cardiomyopathy. Trans $R$ Soc Trop Hyg 1966;60:621-5.

${ }^{23}$ Desmonts G, Couvreur J, Colin J, Peupion J. Vers un diagnostic précoce de la toxoplasmose aiguë. Etude clinique du test de Remington. Nouv Presse Méd 1973;1:319-42.

${ }^{24}$ Couvreur J. Diagnostic sérologique actuel de la toxoplasmose. Le test de Remington. Gaz Méd Fr 1975;4:377-80.

Requests for reprints to: Dr Desanka Sibalić, Institute for Medical Research, PO Box 721, 11001 Beograd, Yugoslavia. 